\title{
EFFECT OF SOIL STRENGTHENING ON RIGID PAVEMENT THICKNESS
}

\author{
Ibrahim Mohamed Ramadan1, Zainab Salah El-Din Hussein2 and Omar Mokhtar \\ Mohamady3 \\ ${ }^{1}$ Civil engineering Department, Faculty of engineering at Shoubra, Benha University, Cairo, Egypt. \\ ${ }^{2}$ Material properties and testing, Housing and Building National Research Center, Cairo, Egypt \\ ${ }^{3}$ B.Sc., Civil Engineering Department, Faculty of engineering at Shoubra, Benha University, Cairo, Egypt
}

\begin{abstract}
The aim of this study is to evaluate the effect of strengthen of soil under concrete slab on its thickness. Rigid pavement strength depends on the rigidity of concrete slab in addition to the effect of soil strength. This research tries to study strengthen of soil under rigid pavement using different compositions of coarse and fine aggregate. The term which expresses soil strength in the AASHTO design equation is the value of the modulus of subgrade reaction $(\mathrm{K})$. Various compositions of fine and coarse aggregate have been tested in the lab. Each sample has been analysed in term of sieve analysis and California bearing ratio (CBR). Using CBR value for each sample and AASHTO equation, the modulus of subgrade reaction has been estimated. Using the estimated value of modulus of subgrade reaction and AASHTO design method for rigid pavement the slab thickness has been estimated for each case. Results have been analysed to get the effect of best composition of coarse and fine aggregate under rigid pavement.
\end{abstract}

KEYWORDS: Rigid pavement, Concrete slab thickness, California bearing ratio, Modulus of subgrade reaction, Coarse and fine aggregate, Soil strengthening.

\section{INTRODUCTION.}

Rigid pavement is the least common type of paving in Egypt-It has special uses in some factories, airports and sometimes petrol stations. Rigid pavement may be dealt with in different vision that leads to see that it may be appropriate for Egypt for many situations.

The cost of bitumen has increased up hence in upcoming years the availability will also be a matter of serious concerns. Egypt imports most of its oil needs and this over-dependence on imports is likely to increase further during the coming years, causing a serious drain on the foreign exchange reserves. Merits of concrete pavements over bitumen pavements are long lasting over 30-40 years, low maintenance, hard surface, reducing fuel consumption, reducing of lighting requirements, improving visibility and the need for required layers under a concrete slab is less [1].

Most researches in rigid pavement focused on concrete slab because the increase in the efficiency of the concrete has a great effect and exceeds the improvement of the soil under the concrete slab although the rigid pavement is based primarily on the strength of the concrete slab, it doesn't mean that there is no need for soil strengthen, Consequently this research, focuses on studying the effect of soil strengthens under a concrete slab on slab thickness to be a first step to further research in this direction. In the experimental program of this research natural material with different mixing ratios have been used however the strength of the soil can be done by some additives such as wastes which are what authors hope to complete the work on the results of this research. After studying the effect of soil strength going towards Study the improvement in the strength of soil under the concrete slab in other researches.

Literature review

As mentioned, a few researches focused on soil strengthening in rigid pavement. According to design, layers under concrete slab may be base layer over subgrade or base and subbase layer over subgrade. 
Hall, J. W. (2005) shows the importance of base layer on the performance of concrete pavement and effect of using stabilized base layers on long and short-term performance. Three types of stabilized base (Asphalt treated base, Cement-treated base, and Lean concrete base) are used. Many details about design considerations discussed to provide a design guide for some rigid pavement cases. As for our subject, the impact of strengthening stabilized base layer was studied, to the conclusion that increase in $(\mathrm{k})$ value of base layer has importance structural benefit in decrease concrete slab thickness especially for high loads design such as Aircraft loads. It can be noted that wheel load stresses on concrete slab decrease with increasing thickness of the stabilized base [7].

About subbase layer, a research paper published on ACPA site (American Concrete Pavement Association) entitled "Stabilized Subbases" shows the benefits of using stabilized subbase in concrete pavement. Stabilized subbases improving the final pavement smoothness because it provides stable and firm support, providing a more erosion resistant, helps to greater use of recycled materials and wastes which saving in materials and costs and provides a higher degree of support ( $\mathrm{K}$ value). Figure (1) shows the effect of ( $\left.\mathrm{K}_{\text {value }}\right)$ on decreasing concrete slab thickness [8].

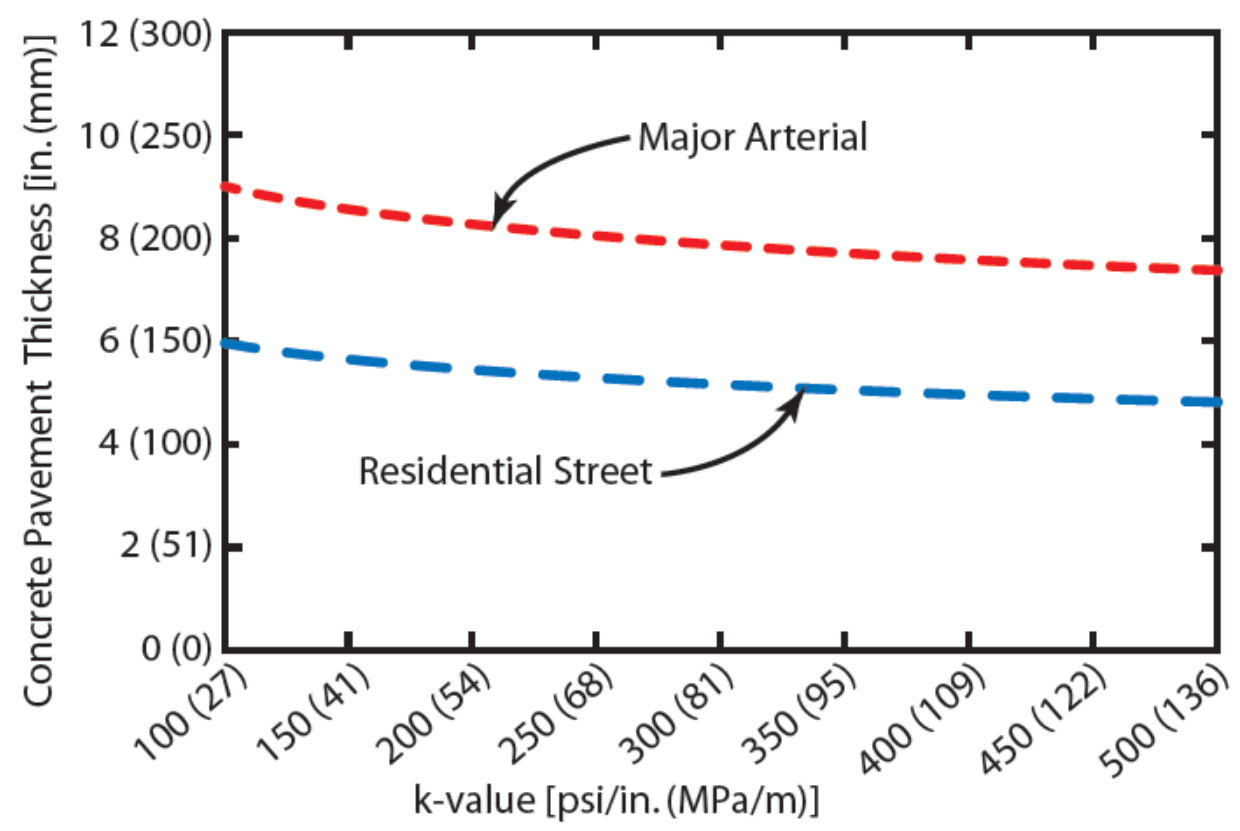

Fig.1. The effect of (K value) on the concrete slab thickness [8].

Bakash, S. A., Sowmith, C., Rakesh, G., \& Rahul, B. (2013) studied use construction and demolition (C\&D) waste and Cement Kiln Dust (CKD) in rigid pavement layers. The conclusions of this study as follows: using CKD increases soil unconfined compressive strength, Recycled Aggregates of Concrete give satisfying results when used in subbase and base layer under a concrete slab, finally soil contained Recycled Aggregates need more water for good compaction [10].

As for the concrete slab, there are many studies interested in improving the efficiency of the concrete slab using some additions and residues instead of natural materials. Some of these studies can be mentioned, for example as follows:

Muscalu, M. T., \& Andrei, R. (2011) studied use recycled aggregate obtained from construction and demolition waste in the concrete mix of rigid pavement slab. Laboratory tests results proved that using recycled aggregate give similar performance to the use of crushed gravel [9].

Mathew, P., Stephen, L., \& George, J. (2013) used steel slag aggregate instead of natural coarse aggregate in concrete pavement. After using steel slag, the compressive strength decreased from $2 \%$ to $19 \%$ with replacement percentage from $20 \%$ to $100 \%$, also the split tensile strength decreased from $3.8 \%$ to $30 \%$ with replacement percentage from $20 \%$ to $100 \%$ [11].

Sumi, N., \& Malathy, R. (2013) showed the experimental investigation of the effect of using steel slag and fly ash in concrete to get economical concrete for rigid pavement. From tests results, the optimum percentage of replacement steel slag as a fine aggregate was $40 \%$. This ratio gives the best results in compressive strength and flexural strength [12].

\section{EXPERIMENTAL INVESTIGATION}

Materials: The materials used are the following: 
First: The Coarse Aggregate is Crushed limestone got from El-saf, El-wedy Egyptian armed forces Quarry, The Visual Inspection was accepted, and testing was done according to AASHTO standards and ASTM standards. The coarse aggregate gradation is shown in figure (2).

According to properties tests specific gravity $=2.6$, Absorption $\%=1.46 \%$, Los Angeles Abrasion Test $($ After 500 revolutions $)=18.4 \%$.

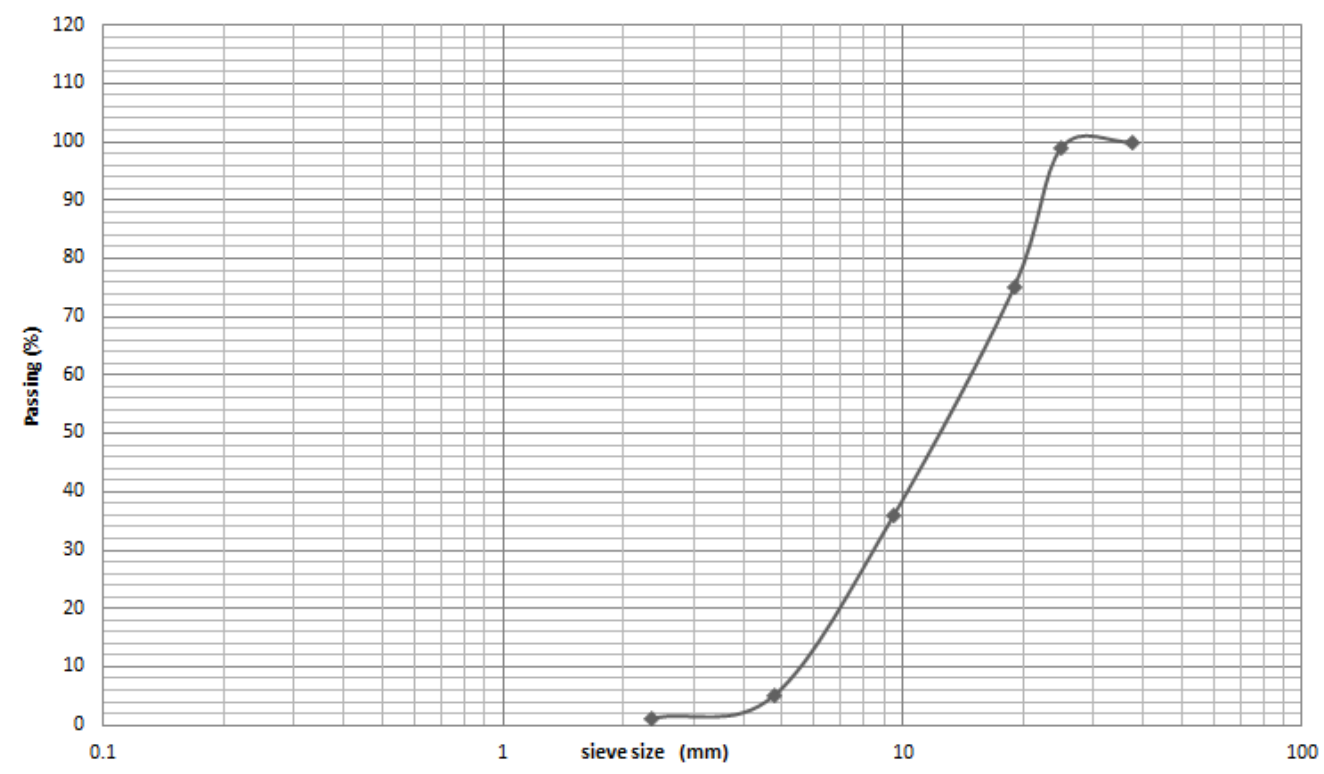

Fig.2. Gradation of coarse aggregate.

Second: The fine aggregate is natural sand. The visual inspection was accepted, and testing was done according to AASHTO and ASTM standards. According to properties tests, specific gravity = 2.65. The fine aggregate gradation is shown in figure (3).

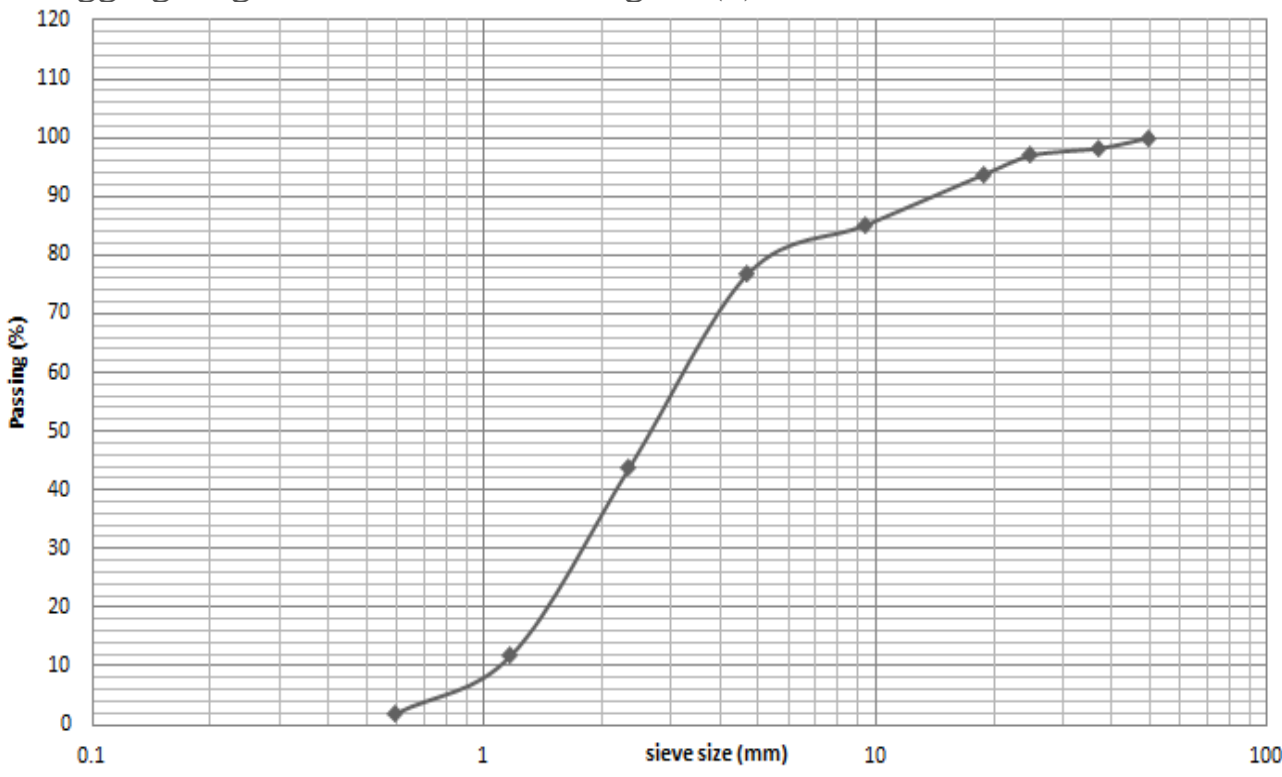

Fig.3. Gradation of fine aggregate.

Tests Conducted: Sieve analysis test [2], Modified Proctor Test [3], and California Bearing Ratio Test [4]. Mixtures: Using the above materials, four mixtures (A, B, C, and D) were made with varying mixing ratios of coarse aggregate and sand. Table (1) shows the mixing ratios for each mix. 
EFFECT OF SOIL STRENGTHENING ON RIGID PAVEMENT THICKNESS

Table1. Mixing ratios for all mixes

\section{Tests results:}

\begin{tabular}{|c|c|}
\hline Mix ID & Mixing ratios \\
\hline A & $100 \%$ Sand \\
\hline B & $75 \%$ Sand \& 25\% Coarse Aggregate \\
\hline C & 50\% Sand \& 50\% Coarse Aggregate \\
\hline D & 25\% Sand \& 75\% Coarse Aggregate \\
\hline
\end{tabular}

Hereafter, there are three charts for each mix to show the following:

- The gradation curve.

- Modified Proctor test results (optimum water content and maximum dry density).

- California Bearing Ratio test result (CBR \%).

For mix (A): figure (4) shows the gradation curve [2].

$100 \%$ Sand

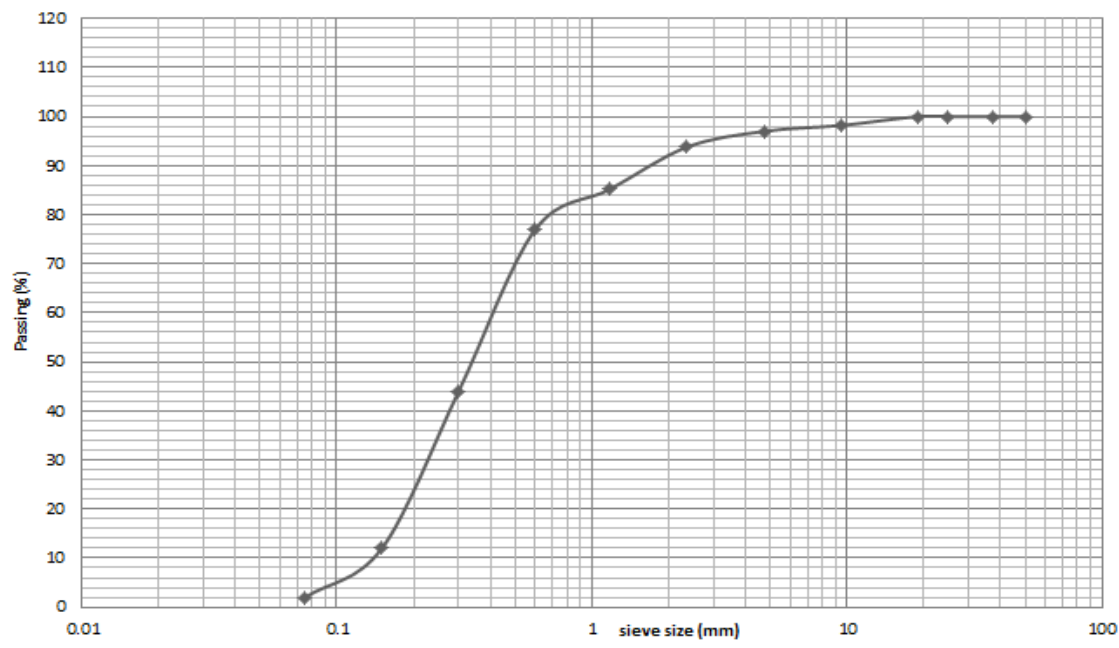

Fig.4. Gradation curve for mix (A).

Figure (5) shows Proctor test chart[3]. From chart maximum dry density $=2.022 \mathrm{gm} / \mathrm{cm}^{3}$ while O.W.C $=9.74 \%$

Proc. $100 \%$ Sand

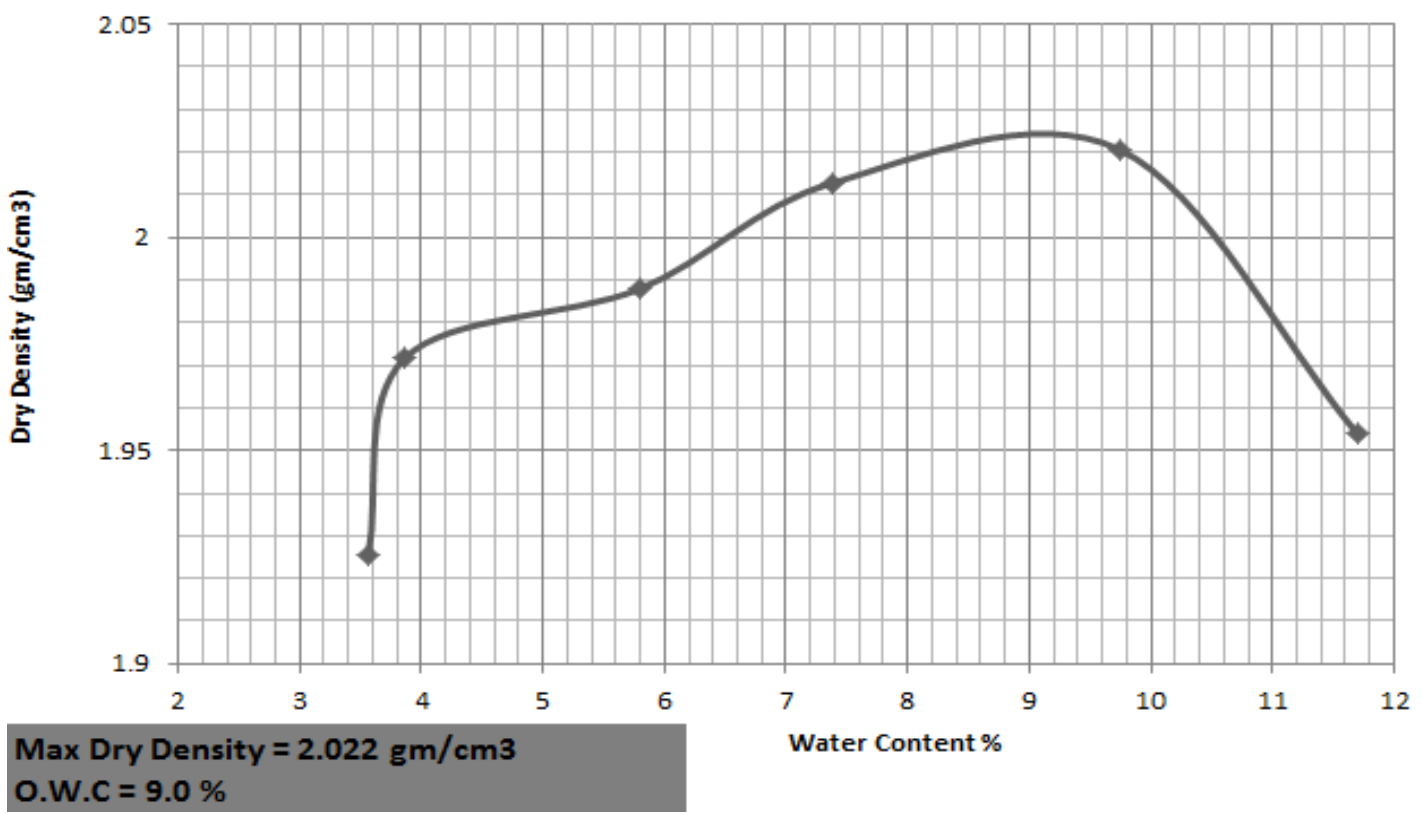

Fig.5. Chart of Proctor test for mix (A) 
Figure (6) shows California Bearing Ratio test chart [4]. According to specifications if $\left(\mathrm{CBR}_{2}>\mathrm{CBR}_{1}\right)$ experiment should be re-tested. After retesting the same results have been got, therefore (CBR value is $24.2 \%)$.

\section{C.B.R.100\% Sand}

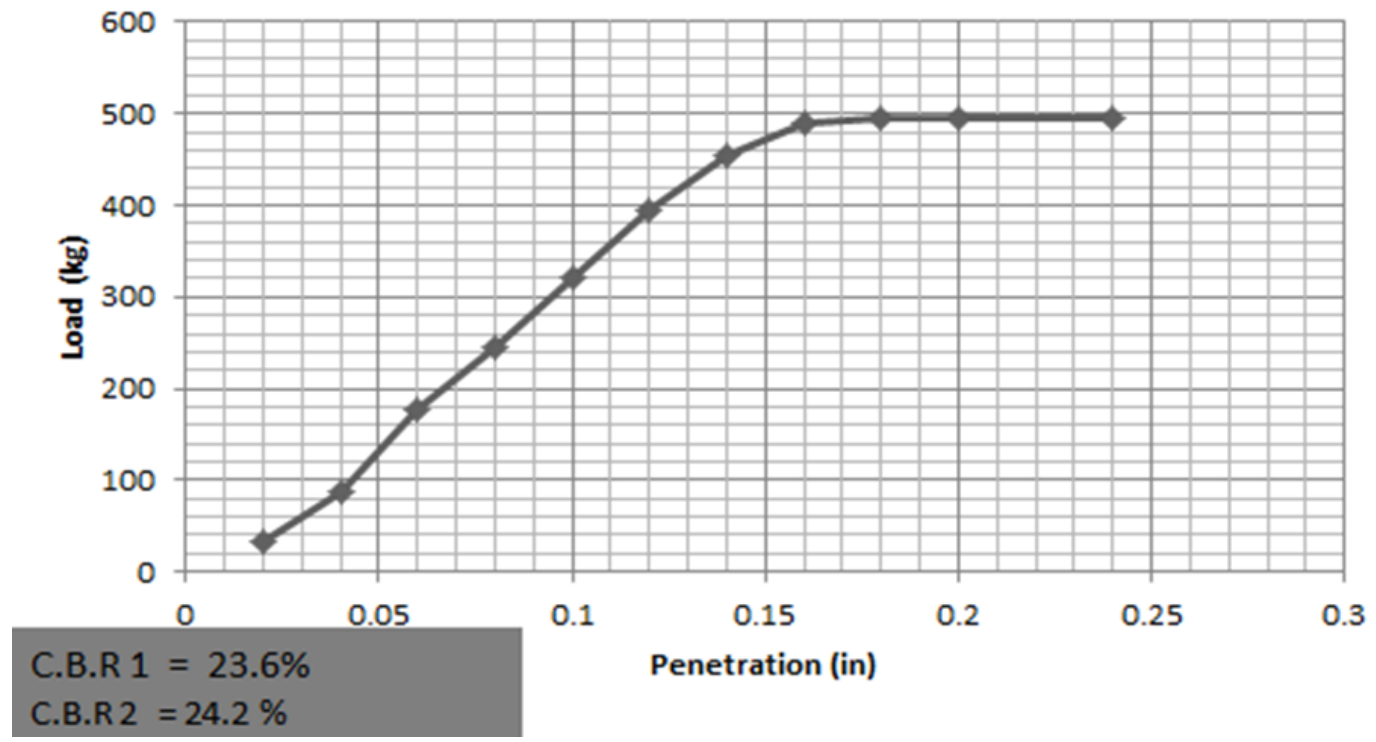

Fig.6. Chart of California Bearing Ratio test for mix (A)

For mix (B): figure (7) shows the gradation curve [2].

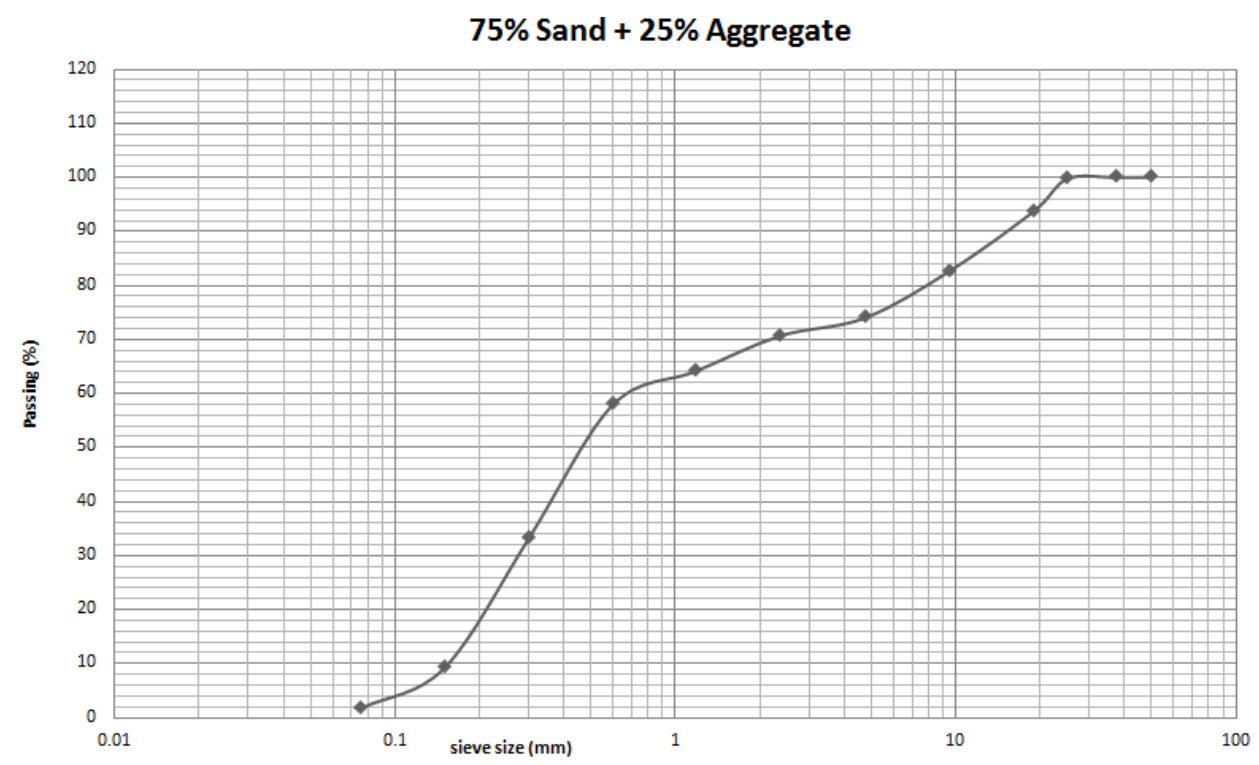

Fig.7. Gradation curve for mix (B).

Figure (8) shows Proctor test chart [3]. From chart maximum dry density $=2.17 \mathrm{gm} / \mathrm{cm}^{3}$ while O.W.C $=8.5 \%$ 


\section{Proc. $75 \%$ Sand $+25 \%$ Aggregate}

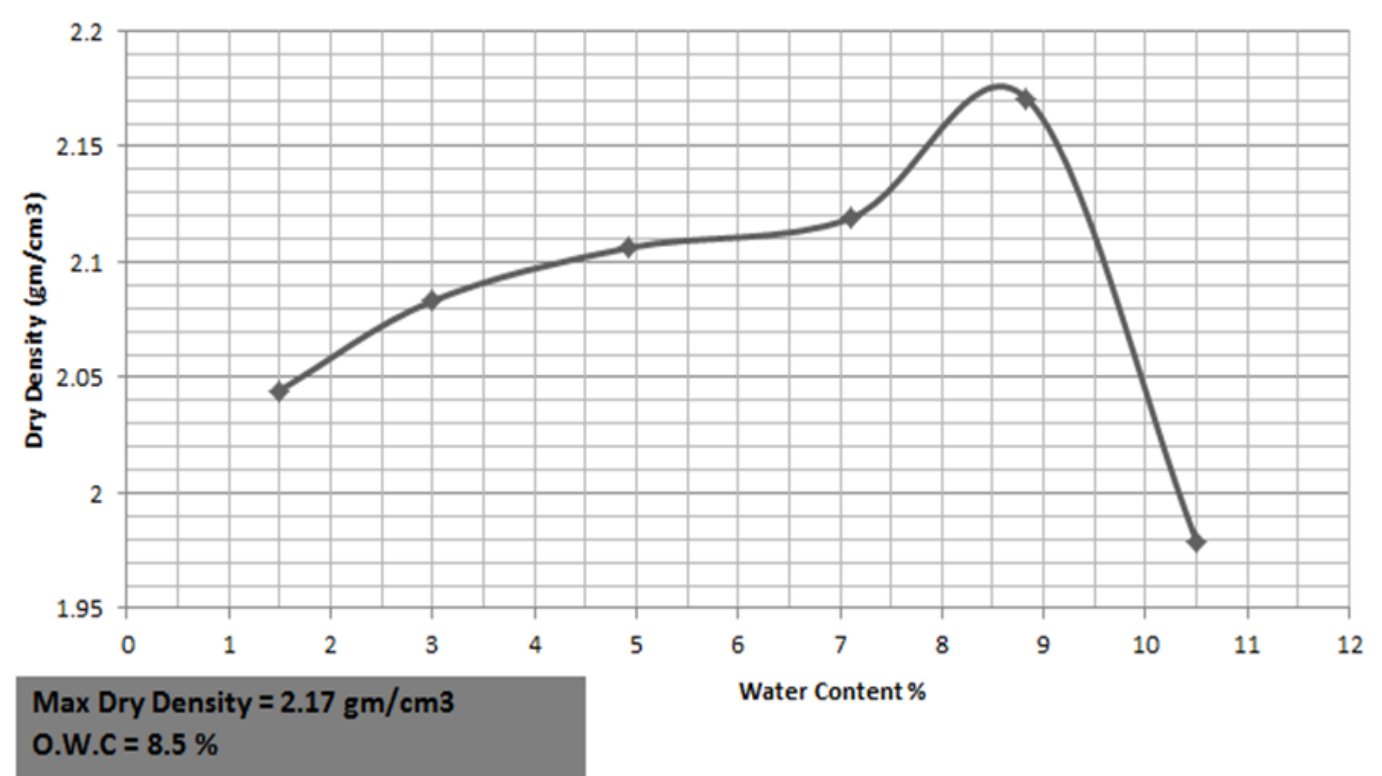

Fig.8. Chart of Proctor test for mix (B)

Figure (9) shows California Bearing Ratio for mix B From chart (CBR value is 49.5\%)

\section{CBR. 75\% Sand + 25\% Aggregate}

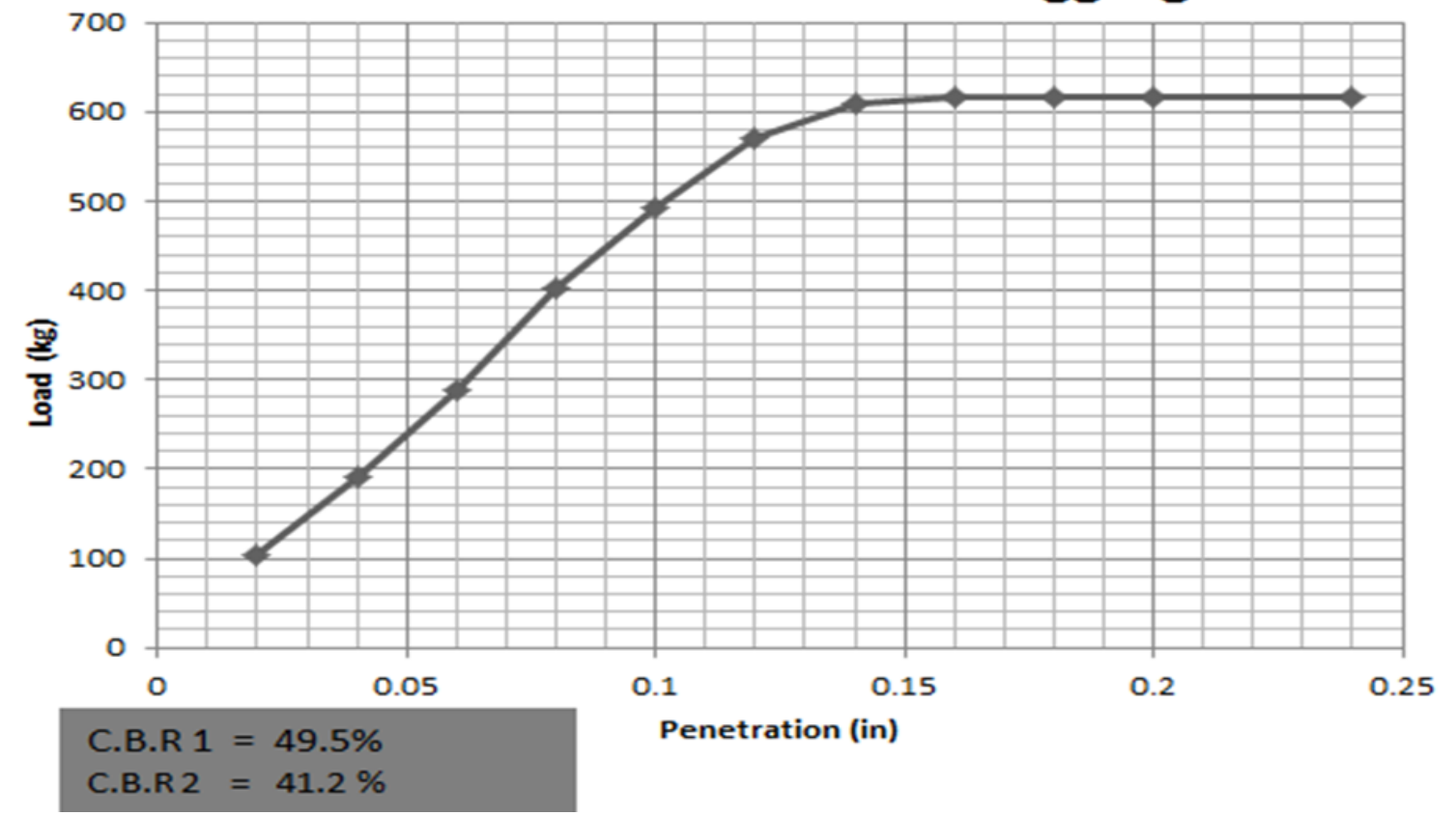

Fig.9. Chart of California Bearing Ratio test for mix (B)

For mix (C): figure (10) shows the gradation curve [2]. 


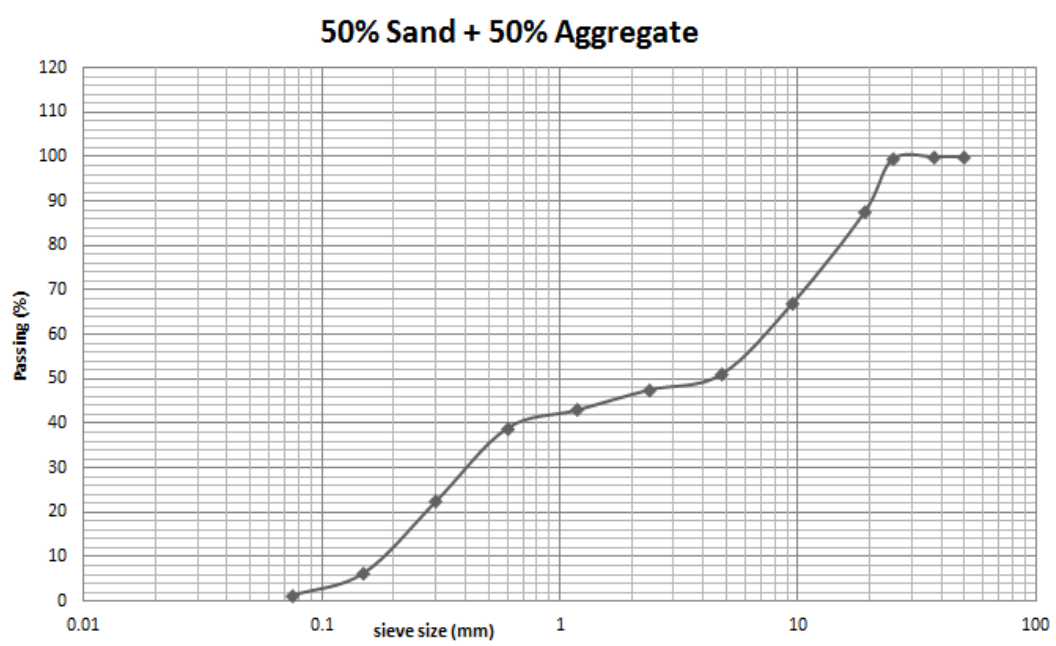

Fig.10. Gradation curve for mix (C)

Figure (11) shows Proctor test chart [3]. From chart, the maximum dry density is $2.315 \mathrm{gm} / \mathrm{cm}^{3}$ while O.W.C is $7.5 \%$

Proc. 50\% Sand + 50\% Aggregate

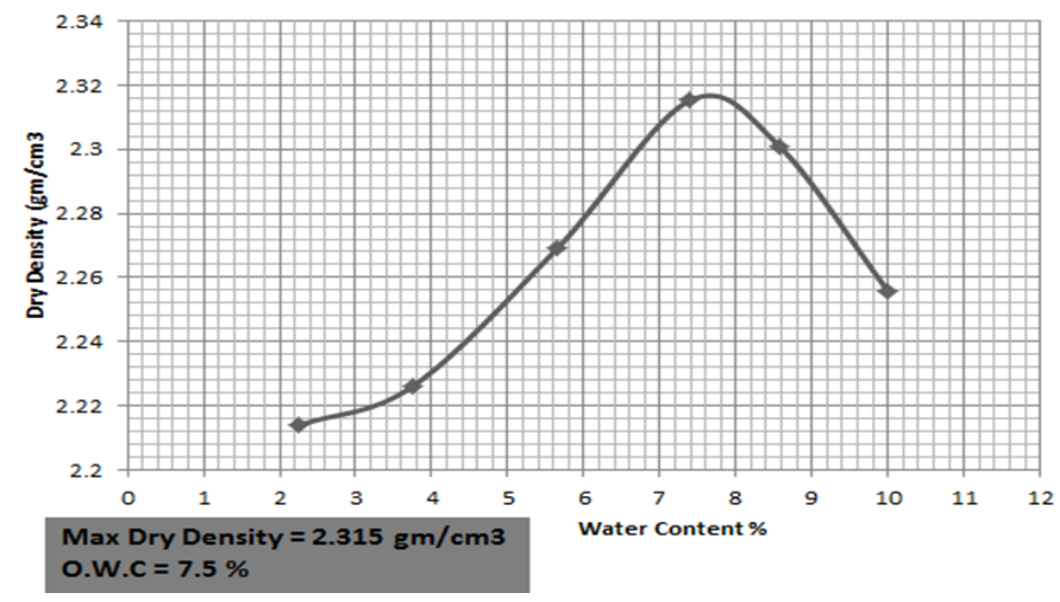

Fig.11. Chart of Proctor test for mix (C)

Figure (12) shows California Bearing Ratio test chart [4]. According to specifications if (CBR2>CBR1) experiment should be re-tested. After retesting the same results have been got, therefore (CBR value is $58.4 \%$ ).

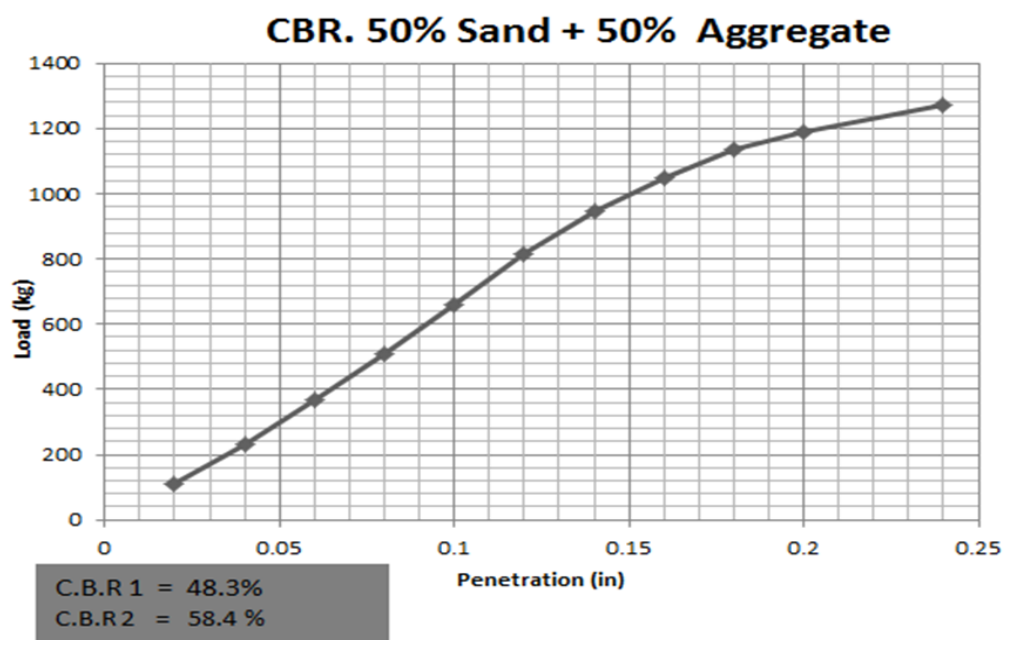

Fig.12. Chart of California Bearing Ratio test for mix (C) 
For mix (D): figure (13) shows the gradation curve [2].

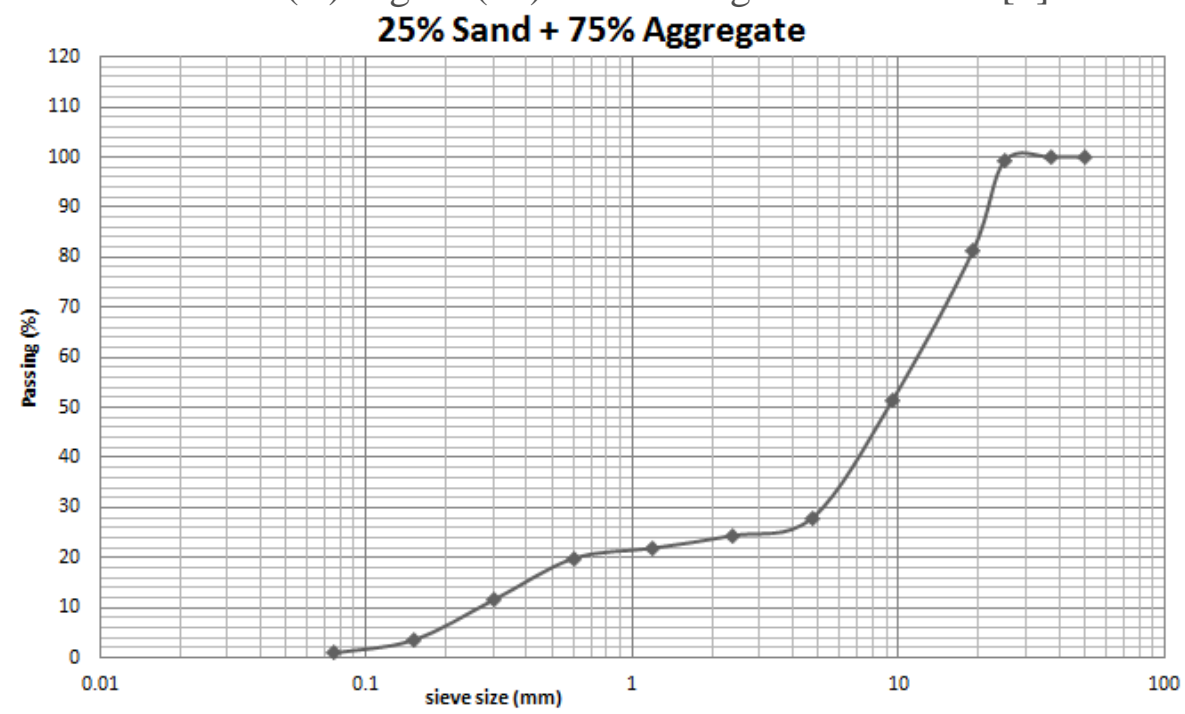

Fig.13. Gradation curve for mix (D)

Figure (14) shows Proctor test chart [3]. From chart maximum dry density $=2.43 \mathrm{gm} / \mathrm{cm}^{3}$ while O.W.C $=7.1 \%$

Proc. 25\% Sand + 75\% Aggregate

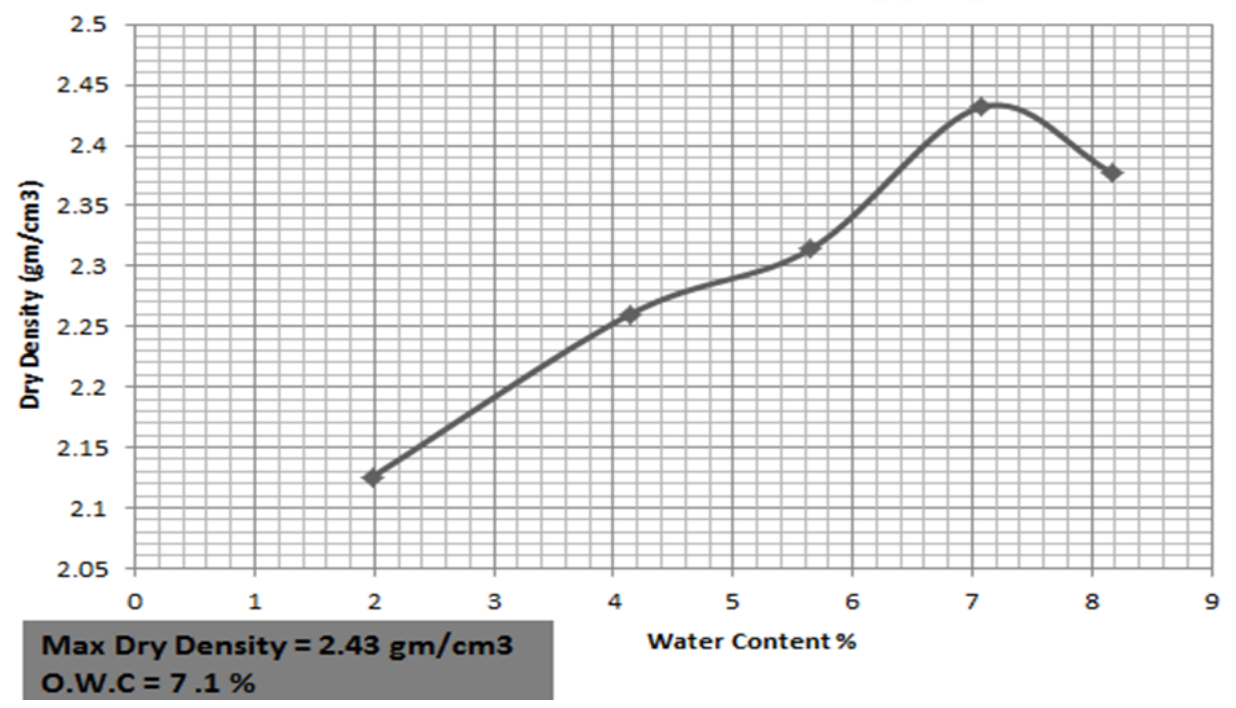

Fig.14. Chart of Proctor test for mix (D)

Figure (15) shows California Bearing Ratio test chart [4]. According to specifications if $\left(\mathrm{CBR}_{2}>\mathrm{CBR}_{1}\right)$ experiment should be re-tested. After retesting the same results have been got, therefore (CBR value is $41 \%)$. 
EFFECT OF SOIL STRENGTHENING ON RIGID PAVEMENT THICKNESS

CBR.75\% Agg. + 25\% sand

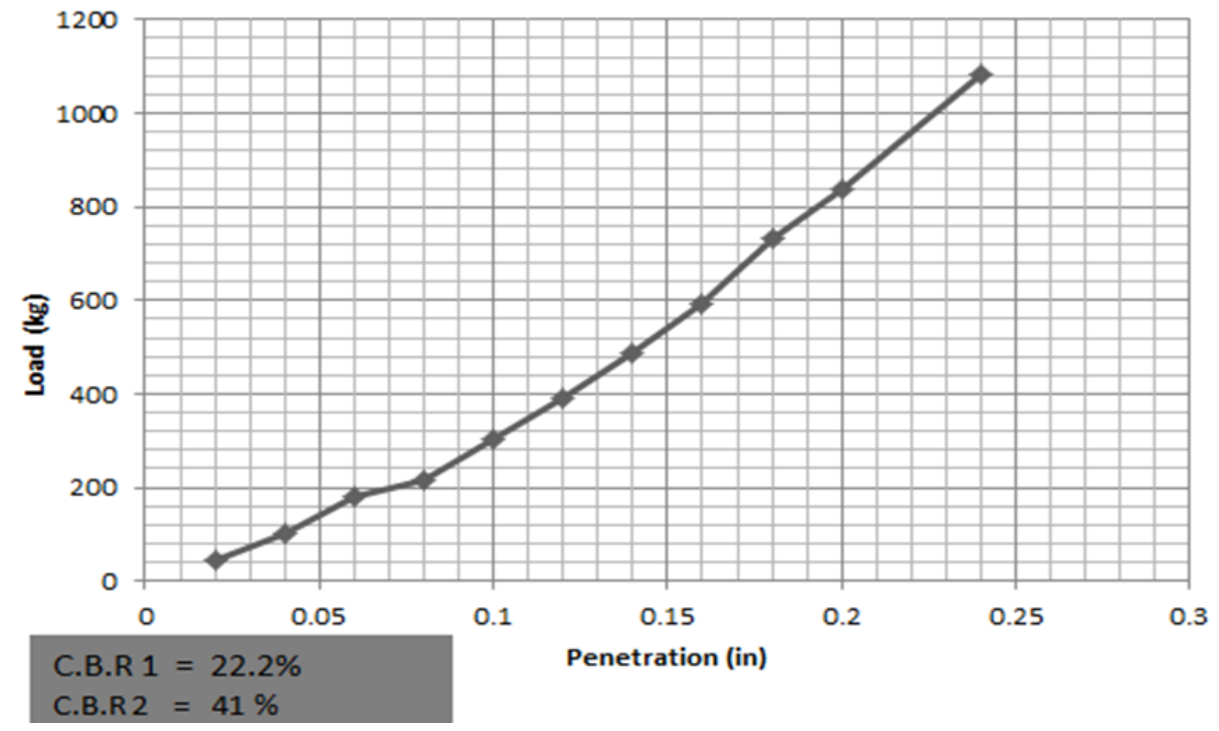

Fig.15. Chart of California Bearing Ratio test for mix (D)

qTable (2) shows a summary of all mixes as following:

Table2. Results for all mixes

\begin{tabular}{|c|c|c|c|c|}
\hline Mix ID. & Mix ratios & O.W.C \% & $\begin{array}{c}\text { Max Dry } \\
\text { Density } \mathrm{gm} / \mathrm{cm}^{3}\end{array}$ & $\begin{array}{c}\text { California } \\
\text { Bearing Ratio } \\
(\text { CBR })\end{array}$ \\
\hline a) & $100 \%$ sand & $9.0 \%$ & 2.022 & $24.2 \%$ \\
\hline b) & $25 \%$ aggregate,75\% sand & $8.5 \%$ & 2.175 & $49.5 \%$ \\
\hline c) & $50 \%$ aggregate, $50 \%$ sand & $7.5 \%$ & 2.315 & $58.4 \%$ \\
\hline d) & $\begin{array}{l}75 \% \text { aggregate } \\
\text {,25\% sand }\end{array}$ & $7.1 \%$ & 2.430 & $41.0 \%$ \\
\hline
\end{tabular}

Results Analysis

Figure (16) shows column chart of results for all mixes. From the chart it can be concluded the following:

- Increasing the percentage of coarse aggregate in the mixture lead to decrease water content value and increase in dry density value,

- The highest value of CBR\% obtained from the mix (C) (50\% sand, 50\% coarse aggregate).

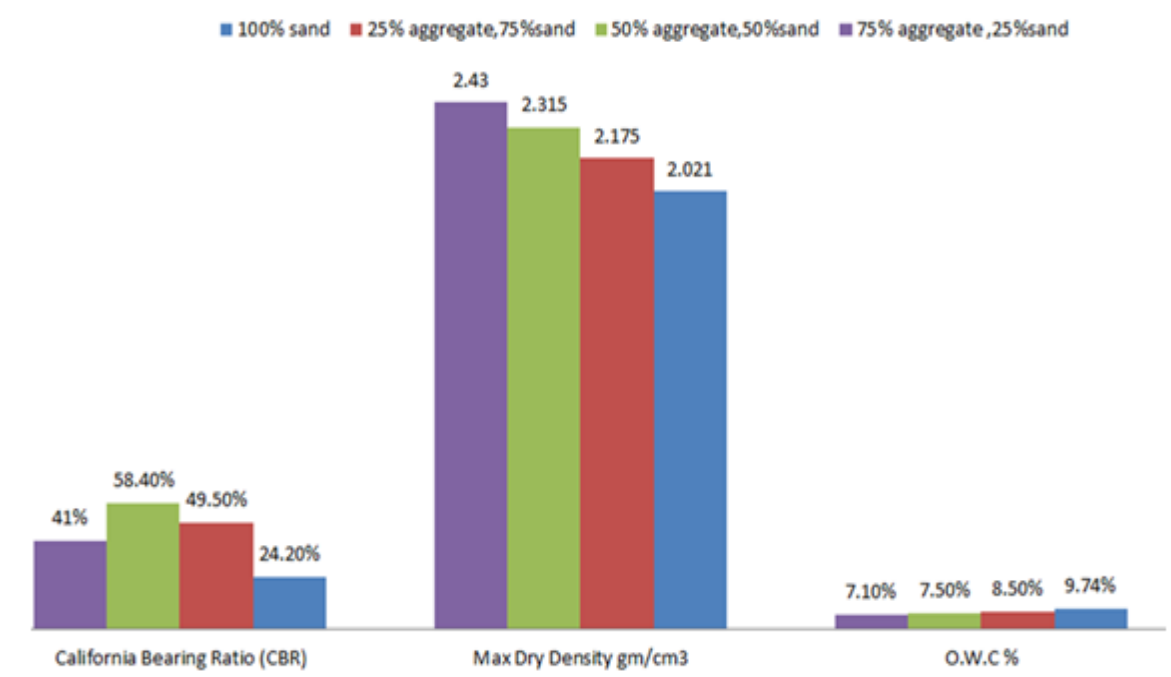

Fig.16. Column Chart of results for all mixes 
AASHTO Design Equation for Rigid pavement has been used. The design equation is shown in figure (17). All parameters in this equation are put with constant value except the values for (D and $\mathrm{K})$. These two variables will be changed according to the research results to show the effect of increasing subgrade reaction value to decreasing slab depth.

$$
\left.\log \left(W_{18}\right)=\left(Z_{R} \cdot S_{0}\right)+7.35 \cdot \log (D+1)-0.06+\frac{\log \left(\frac{\Delta P S I}{4.5-1.5}\right)}{1+\frac{1.624 \cdot 10^{7}}{(D+1)^{8.46}}}+\left(4.22-0.32 \cdot P_{t}\right) \cdot \log \frac{S_{C} \cdot C_{d} \cdot\left(D^{0.75}-1.132\right)}{215.63 \cdot J \cdot\left[D^{0.75}-\frac{18.42}{\left(\frac{\left.E_{c}\right)^{0.25}}{k}\right)}\right]}\right]
$$

Fig.17. AASHTO equation design for rigid pavement [5]

To get modulus of subgrade reaction $(\mathrm{K})$ value from $(\mathrm{CBR} \%)$ value there are many equations and charts. In this design example, a chart from (ECP 1998) has been used [6].

The values here under are used for parameters:

$\mathrm{Zr}=-1.282, \mathrm{~S}=0.35, \mathrm{P}_{\mathrm{o}}=4.5, \mathrm{P}_{\mathrm{t}}=3, \mathrm{D}_{\mathrm{PSI}}=1.5, \mathrm{Sc}=600, \mathrm{Cd}=1, \mathrm{~J}=2.7, \mathrm{Ec}=4,000,000$

Table (3) shows the (K) values corresponding to (CBR \%) values and slab thickness values according to different values of $(\mathrm{K})$.

Table (3) shows the results from design equation as following:

\begin{tabular}{|c|c|c|c|}
\hline Mix ID & CBR\% & $\mathrm{K}\left(\mathrm{kg} / \mathrm{cm}^{5}\right)$ & Slab Thickness D $(\mathrm{cm})$ \\
\hline A & $24.2 \%$ & 8.065 & 22.6 \\
\hline B & $49.5 \%$ & 14 & 21.59 \\
\hline C & $58.4 \%$ & 15.7 & 21.3 \\
\hline D & $41 \%$ & 12.09 & 21.97 \\
\hline
\end{tabular}

Table3. Results from design equation

From table (3), it can be concluded that increasing in (CBR \%) and (K) values leads to decrease in concrete slab thickness.

The difference between the highest value of slab thickness which corresponding to the lowest value of $(\mathrm{k})$ and the lowest value of slab thickness which corresponding to the highest value of (k) equal $1.3 \mathrm{~cm}$ that mean more saving in concrete. This means a big saving in cost because for example saving $1.3 \mathrm{~cm}$ in depth of concrete slab in $30 \mathrm{~km}$ highway and have $20 \mathrm{~m}$ width lead to saving about $7,800 \mathrm{~m}^{3}$ concrete.

Limited budgets and rising costs represent the biggest problem facing infrastructure projects in countries, from this point, scientific research is important in helping governments find ways to save costs.

\section{CONCLUSIONS}

Reference to the above analysis, the following can be concluded:

- Increasing the (CBR \%) value improves the strength of the soil by increasing the modulus of subgrade reaction value $(\mathrm{K})$.

- The Mixture which contains (50\% natural sand \& 50\% coarse aggregate "crushed limestone") has the highest value of (CBR \%) equal to $58 \%$.

- The Mixture which contains (100\% natural sand) has the lowest value of (CBR \%) equal $24 \%$.

- Changing in the value of (CBR \%) from the mix (A) with value equal $24 \%$ to mix (C) with $(\mathrm{CBR} \%)$ value equal $58 \%$ leads to saving in concrete slab depth about $1.3 \mathrm{~cm}$.

- $(1.3 \mathrm{~cm})$ saving in concrete slab thickness leads to saving thousands of concrete cubic meters in big projects. 
- The concrete slab thickness is greatly affected by the efficiency of the concrete. However, the strength of the soil, under the concrete slab, has less effect. But, of course, this doesn't mean to neglect improving the characteristics of this soil because it is of great importance especially if improving the concrete slab isn't available.

\section{RECOMMENDATIONS}

- This research is based on laboratory investigation and need for field trial is recommended.

- Conducting more tests on the mixtures to evaluate its suitability for using in different layers under concrete slab according to specifications.

- Using different wastes to improve soil strength more and more which leads to more decreasing in concrete slab thickness to save more costs may be checked.

- Using of wastes is recommended to improve soil strength not only from the engineering vision of soil improvement and the reduction of the thickness of the concrete slab, but also from the environmental prospect of waste disposal and disposal expenses, as well as reducing the consumption of natural materials in infrastructure projects. Therefore, the importance of this research lies in the need to complete the path in this direction, which has a significant economic impact in light of economic crises facing governments

\section{REFERENCES}

[1] Wang, G., \& Wang, Y. (2016). Can Steel Slag Be Used as an Aggregate in Concrete and How? A Technical Approach by and Testing and Theoretical Molding. In Construction Research Congress 2016 (pp. 240-249).

[2] ASTM, C. (2005). 136, Standard Test Method for Sieve Analysis of Fine and Coarse Aggregates. Annual Book of Standards, 4(02).

[3] ASTM, D. 1557, Standard test methods for laboratory compaction characteristics of soil using modified effort.

[4] ASTM, D. (1883). Standard test method for CBR (California Bearing Ratio) of laboratorycompacted soils. Annual Book of ASTM Standards, 4.

[5] American Association of State Highway, \& Transportation Officials. (1993). AASHTO Guide for Design of Pavement Structures, 1993 (Vol. 1). AASHTO.

[6] ECP 104 (1998) Egyptian Code of Principles for design and implementation requirements of urban and rural roads. Part six.

[7] Hall, J. W. (2005). Stabilized and Drainable Base for Rigid Pavement: A Design and

Construction Guide. Programs Management Office.

[8] ACPA (2008).Stabilized Subbases; Stabilized Subbases,

http://1204075.sites.myregisteredsite.com/downloads/TS/EB204P/TS204.7P.pdf

[9] Muscalu, M. T., \& Andrei, R. (2011). Use of recycled aggregates in rigid pavement

construction. Buletinul Institutului Politehnic din lasi. Sectia Constructii, Arhitectura, 57(2), 69.

[10] Bakash, S. A., Sowmith, C., Rakesh, G., \& Rahul, B. (2013, April). A Review of the Use of Recycled Materials in Rigid Pavements. International Journal of Engineering Research and Technology, 2(4).

[11] Mathew, P., Stephen, L., \& George, J. (2013). Steel slag ingredient for concrete pavement. International Journal of Innovative Research in Science, Engineering and Technology, 2(3), 710 714.

[12] Sumi, N., \& Malathy, R. (2013). Experimental investigation on effect of fly ash and steel slag in concrete pavements. International Journal of Research in Engineering \& Technology (IJRET), $1(2), 117-124$. 